\title{
Toxicity of insecticides used in melon crop to Opius scabriventris, a natural parasitoid of Liriomyza sativae
}

\author{
Francisco Edivino Lopes Silva ${ }^{1} \mathbb{0}$, Ewerton Marinho Costa ${ }^{2} \mathbb{0}$, \\ Carlos Eduardo Souza Bezerra ${ }^{3}$, Elton Lucio Araujo ${ }^{1}{ }^{\circ}$

\footnotetext{
1 Universidade Federal Rural do Semi-Árido, Mossoró, RN, Brasil. E-mail: edivino_ufersa@hotmail.com; elton@ufersa.edu.br

2 Universidade Federal de Campina Grande, Pombal, PB, Brasil. E-mail: ewertonmarinho10@hotmail.com

${ }^{3}$ Centro Universitário de Várzea Grande, Várzea Grande, MT, Brasil. E-mail: carlos.esb@gmail.com
}

ABSTRACT: Opius scabriventris Nixon is an important parasitoid of the leafminer Liriomyza sativae Blanchard in the melon crop (Cucumis melo L.). Knowing the impact of insecticides on this parasitoid may help the integrated pest management, thus allowing recommending insecticides with a lower impact. Therefore, this study evaluated lethal and sublethal toxicities of select insecticides used in the melon crop for controlling leafminers on the 0 . scabriventris parasitoid. The toxicity of the insecticides was assessed by confining adults of the parasitoid on freshly sprayed plastic containers, under laboratory conditions. The evaluated insecticides were abamectin, chlorantraniliprole, cyromazine, spinetoram, spinosad, in addition to the negative control treatment (distilled water). The sublethal effect of the insecticides was studied through the parasitism of leafminer larvae by surviving parasitoids. Among the evaluated insecticides, abamectin, spinetoram and spinosad were the most toxic to 0 . scabriventris; while chlorantraniliprole and cyromazine demonstrated low toxicity to the parasitoid, albeit causing reduction in its parasitism capacity.

\section{Toxicidade de inseticidas utilizados na cultura do meloeiro}

\section{para Opius scabriventris, um parasitoide natural de Liriomyza sativae}

RESUMO: Opius scabriventris Nixon é um parasitoide da mosca-minadora Liriomyza sativae Blanchard na cultura do meloeiro (Cucumis melo L.). O conhecimento do impacto de inseticidas sobre esse parasitoide pode auxiliar no manejo integrado de pragas visando a sua preservação através da recomendação de inseticidas de menor impacto. Assim, este estudo avaliou a toxicidade letal e subletal de alguns inseticidas utilizados na cultura do melão ao parasitoide. A toxicidade dos inseticidas foi avaliada por meio do contato dos parasitoides com superfície recém-pulverizada em condições de laboratório. Os inseticidas avaliados foram abamectina, clorantraniliprole, ciromazina, espinetoram, espinosade, além do tratamento controle negativo (água destilada). $O$ efeito subletal dos inseticidas foi estudado por meio da avaliação da capacidade de parasitismo dos parasitoides que sobreviveram aos ensaios de toxicidade. Entre os inseticidas avaliados, abamectina, espinetoram e espinosade foram os mais tóxicos a 0 . scabriventris. Os inseticidas clorantraniliprole e ciromazina apresentaram baixa toxicidade a 0 . scabriventris, embora tenham ocasionado redução na capacidade de parasitismo do mesmo.

Palavras-chave: controle biológico; controle químico; Cucumis melo; manejo integrado de pragas; seletividade 


\section{Introduction}

The leafminer Liriomyza sativae (Blanchard, 1938) (Diptera: Agromyzidae) is an important pest in the melon crop (Cucumis melo L., 1753 ) in Brazil (Araujo et al., 2013; Ferreira et al., 2017). The larvae of this agromizid consume the leaf mesophyll, causing the reduction of the plant photosynthetic capacity and the total soluble solids content ( ${ }^{\circ}$ Brix) of the fruit (Araujo et al., 2013; Costa et al., 2017).

In several regions worldwide, parasitoids are deemed as important biological controlling agents that assist in regulating the population of leafminers of the genus Liriomyza (Liu et al., 2011). In Brazil, the larva-pupa endoparasitoid Opius scabriventris (Nixon, 1955) (Hymenoptera: Braconidae) is reported as one of the main natural enemies of the leafminers (Costa-Lima et al., 2014; Araujo et al., 2015). Besides Brazil, this parasitoid is mentioned in several countries of South America, such as Argentina, Peru or Chile and, in some regions where 0 . scabriventris was reported, the natural parasitism rates were over 50\% (Salvo \& Valladares, 1995). Furthermore, this parasitoid has high reproductive potential, capable of parasitizing 196.1 larvae individuals of $L$. sativae, also having a short egg-adult development time (14.27 days) (Foba et al., 2015; Costa-Lima et al., 2019).

One of the main difficulties in inserting the biological control in melon-cultivated areas is integrating this said method with the chemical control in a harmonious manner, since applying certain insecticides can affect negatively the populations of natural enemies of the pests (Tirello et al., 2013; Loetti \& Bellocq, 2017). In the melon-production areas intended for export, in the Northeast Region of Brazil, averagely four to five insecticide applications are used for controlling the leafminer, between the flowering and fruiting phases. The applications are held according to the pest monitoring and the main products used are abamectin, cyromazine, cyantraniliprole and spinetoram. In addition to leafminers, other pests such as the whitefly and pickleworm also require controlling measures.

Besides the lethal effects (direct mortality), insecticides can also cause sublethal effects on the natural enemies, interfering in biological and behavior aspects, such as fertility, development, longevity, mobility and foraging capacity, for example (Cabral et al., 2011; Biondi et al., 2013).

Therefore, for an integrated and efficient use of the biological and chemical controls, within an integrated management system of the leafminer in melon, it is essential knowing the toxicity of the insecticides used in the crop on the natural enemies. Information related to the toxicity of these insecticides on the parasitoids of leafminers is still scarce. In Brazil, it has only been reported that the abamectin and cartap insecticides are lethal while the cyromazine is selective to the $O$. scabriventris parasitoid, at the maximum doses that are recommended for controlling the leafminer in the melon crop (Araujo et al., 2015).

In addition to the scarcity of studies, new insecticides have been recommended for controlling pests in the
Brazilian melon crop, such as diamide chlorantraniliprole, and spinosyn spinetoram. Thus, knowing that the response to insecticides is species-specific, studies assessing the effect of new insecticides on the natural enemies need to be conducted. Results with chlorantraniliprole and spinetoram have demonstrated variations in the results between low and high impact for parasitoids (Moscardini et al., 2014; Abbes et al., 2015; Barros et al., 2018; Muslim et al., 2018), having no information on these insecticides impact on 0 . scabriventris.

In light of the foregoing, this study evaluated the lethal and sublethal effects of the insecticides chlorantraniliprole, spinosad and spinetoram on the $O$. scabriventris parasitoid, in comparison with the insecticides abamectin and cyromazine.

\section{Materials and Methods}

The study was conducted in the Laboratory of Applied Entomology from the Federal Rural University of the Semi-arid Region (UFERSA), Mossoró, Rio Grande do Norte, Brazil. The bioassays were held in a room with controlled temperature $\left(25 \pm 1{ }^{\circ} \mathrm{C}\right.$, with relative humidity of $65 \pm 10 \%$ and a 12 -hour photophase), by using adults of the $O$. scabriventris parasitoid, regardless of their sex, with ages between 24 and $96 \mathrm{~h}$, hailing from a breeding in the very laboratory, which followed the methodology described in Silva (2008).

The toxicity of the insecticides was evaluated through contact of the parasitoids with the internal surface of freshly sprayed plastic containers $(8 \mathrm{~cm}$ height $\times 8 \mathrm{~cm}$ diameter) (defined herein as "arenas"), according to the methodology employed by Araujo et al. (2015). These arenas had openings at their top and side parts, closed with a fine mesh screen in order to allow the air circulation inside. During bioassays, the parasitoids were fed with a solution composed by honey + water ( $10 \%$ of honey).

Treatments consisted in five insecticides, of which four are used in the melon crop and one is used in the watermelon crop (Citrullus lanatus Thumb, 1794) for controlling the leafminer (Table 1). All insecticides were applied at their maximum dosages and following the recommendations by the manufacturer (Agrofit, 2020). Taking into account that abamectin and cyromazine have high and low toxicity, respectively (Araujo et al., 2015), these insecticides were used as a parameter for assessing the toxicity degree of the new products chlorantraniliprole, spinosad and spinetoram. As a negative control group, distilled water was used.

The bioassay arenas were sprayed by using a hand-held sprayer (Guarany $1.25 \mathrm{~L}$ compression sprayer) with flow rate of $0.58 \mathrm{~mL} \mathrm{~s}^{-1}$ and mean application rate of $0.00583 \mathrm{~mL} \mathrm{~cm}$, according to the recommendations of Sterk et al. (1999). The mean volume calculation proceeded in accordance with the method proposed by Carvalho et al. (2002), in which 10 discs of filter paper with diameter of $13 \mathrm{~cm}$ were individually weighed and then, in sequence, sprayed with distilled water. The mean was obtained by the difference between the wet and dry weights of the filter paper. After spraying the treatments, adults of the $O$. scabriventris parasitoid were released inside 
Table 1. Insecticides evaluated as their toxicity to the Opius scabriventris parasitoid.

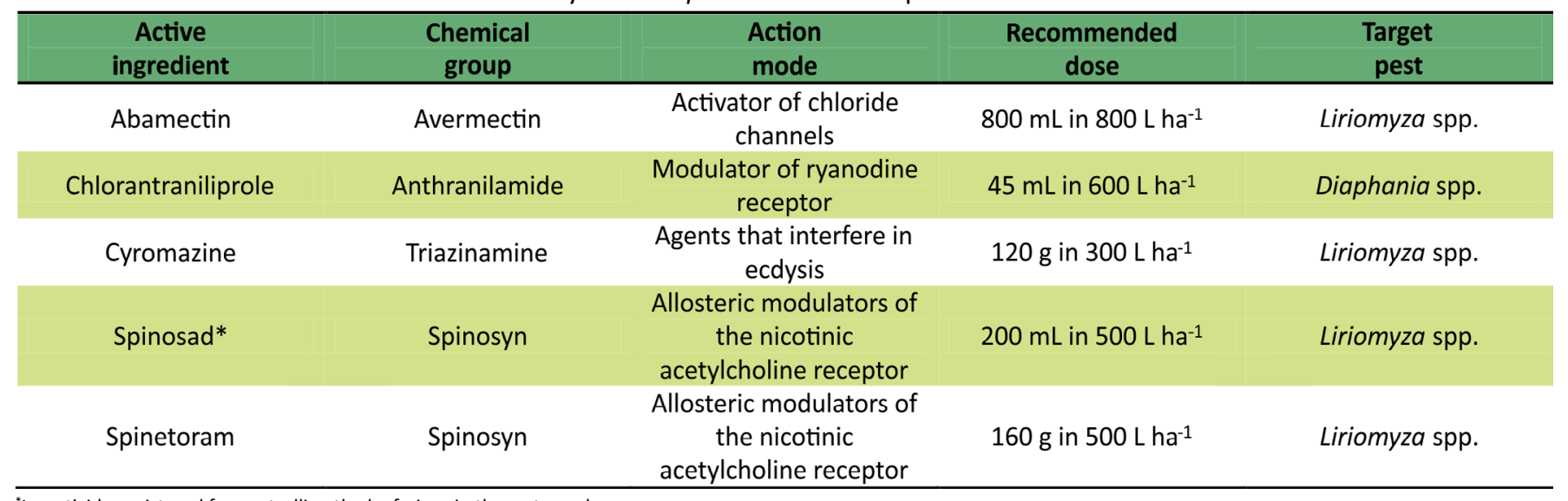

"Insecticide registered for controlling the leafminer in the watermelon crop.

the arenas, aided by an entomological aspirator, and exposed to the freshly sprayed surface. Mortality was evaluated at 1 , $2,3,4,5,6,12,24,48$ and $72 \mathrm{~h}$ after releasing the parasitoids, which were considered as dead when they remained immobile after stimulated with a thin brush.

The toxicity degree was evaluated based on the indexes proposed by the IOBC (International organization for biological and integrated control of noxious animals and plants) and each product was classified as the following: harmless ( $E<$ $30 \%$ ), little harmful $(30 \% \leq E \geq 79 \%)$, moderately harmful $(80 \%$ $\leq E \geq 99 \%$ ) and harmful ( $>99 \%)$, where the $E$ stands for the percentage of adult mortality.

For the parasitoids that survived after $72 \mathrm{~h}$ of exposure, the parasitism capacity of their females was evaluated. For that matter, 10 couples were paired with the remaining survivors and were placed in a cage $(34 \mathrm{~cm}$ high $\times 10 \mathrm{~cm}$ in diameter) containing a melon plant infested with 10 larvae from the second instar of $L$. sativae, which then remained exposed to parasitism for a $24 \mathrm{~h}$ period. The infestation of melon plants was with a $L$. sativae population kept in laboratory (temperature of $25 \pm 1{ }^{\circ} \mathrm{C}$, relative humidity of $65 \pm 10 \%$ and a 12 hour photophase) following the breeding methodology described by Araujo et al. (2007). After their exposure to the parasitoid, the infested leaves were removed from the plants and individually put in plastic trays, which were placed in a room with controlled temperature $\left(25^{\circ} \mathrm{C} \pm 2,70 \% \pm 10 \%\right.$ of $\mathrm{RH}$ and a 12-hour photophase), remaining there until the pupal stage. These were then counted and placed in Petri dishes, closed with a plastic wrap until emergence of adults. Then, the number of adults emerged (parasitoid or fly) was counted.

Both the toxicity and parasitism bioassays were held in a completely randomized design, consisting of six treatments. When evaluating the toxicity of insecticides on $O$. scabriventris, each treatment consisted of 20 replicates, with each one consisting of an arena containing five adult insects, regardless of their sex. In the parasitism capacity bioassay, every treatment consisted of 10 replicates, each composed of a parasitoid couple.

In the toxicity bioassay, the mortality percentages were corrected by the Abbott formula (Abbott, 1925). Due to the data not meeting the assumptions of normality and/or homogeneity of variance, even after transformations, the means were subjected to the Kruskal-Wallis non-parametric test at the $5 \%$ significance level. In addition to this, the data obtained were also subjected to survival analysis, with model contrasts made aiming to group treatments that did not significantly differ in the speed at which they caused mortality, in a single curve, using the Weibull distribution for censored data with the 'survival' package (Therneau, 2019) for the $R$ statistical software (R Development Core Team, 2019). For every group formed, the lethal time $50\left(\mathrm{LT}_{50}\right)$ was estimated. Regarding the parasitism capacity data, the means were subjected to the Kruskal-Wallis non-parametric test at a $5 \%$ significance level using the R software.

\section{Results and Discussion}

The insecticides spinetoram, abamectin and spinosad were the most toxic to $O$. scabriventris, causing high parasitoid mortality after $72 \mathrm{~h}$ of exposure (Table 2). The insecticides chlorantraniliprole and cyromazine demonstrated low toxicity (harmless) promoting an equally low mortality of $O$. scabriventris, having rates of $6 \%$ and $16 \%$, respectively (Table 2).

The insecticides abamectin, spinosad and spinetoram caused a marked mortality after 12 hours of exposing the parasitoids to insecticides, reaching up to mortality rates of $90 \%, 100 \%$ and $100 \%$, respectively, within 24 hours of

Table 2. Mortality (\%) of the Opius scabriventris parasitoid, after $72 \mathrm{~h}$ of exposure in a freshly sprayed surface, under laboratory conditions.

\begin{tabular}{cc}
\hline Treatment & Mortality* $(\%)$ \\
\hline Abamectin & $100.0 \mathrm{a}$ \\
Spinetoram & $100.0 \mathrm{a}$ \\
Spinosad & $94.0 \pm 0.14 \mathrm{a}$ \\
Cyromazine & $16.0 \pm 0.24 \mathrm{~b}$ \\
Chlorantraniliprole & $6.0 \pm 0.13 \mathrm{c}$ \\
Control & $0.0 \pm 0.00 \mathrm{~d}$ \\
\hline
\end{tabular}

*Means followed by the same letter in the column do not differ from each other by the Kruskal-Wallis test at the $5 \%$ significance level. 
exposure (Figure 1). Abamectin and spinosad had a $\mathrm{LT}_{50}$ value of $11.51 \mathrm{~h}$, while spinetoram had $\mathrm{LT}_{50}$ of $5.21 \mathrm{~h}$, causing insects to die faster (Figure 1 ). The insecticides cyromazine and chlorantraniliprole both demonstrated low mortality (Figure 1). It is noteworthy that chlorantraniliprole had a $\mathrm{LT}_{50}$ statistically equal to the negative control group (Figure 1).

The high toxicity of abamectin had already been observed by Araujo et al. (2015) using the same dosage as the present study. The results confirm that this insecticide is toxic to the parasitoid $O$. scabriventris, both through contact with freshly sprayed surface and through contact with dry product residues. The high mortality observed for the spinosad and spinetoram insecticides is probably related to their mode of action associated with the nervous system, since they act as agonists of the nicotinic acetylcholine receptor in this very system, common to target and non-target organisms, which leads to the insect having muscle contractions, tremors, paralysis, feeding interruption and death (Salgado et al., 1998; Biondi et al., 2012). The harmful effect of spinetoram and spinosad on Braconidae parasitoids was reported by Abbes et al. (2015), who verified $100 \%$ mortality on Bracon nigricans (Szépligeti, 1901) after exposure to the products in the dosages of 731 and $25 \mathrm{~mL}$ per $1000 \mathrm{~L}$, respectively, under different temperatures. Specifically for parasites of the genus Opius, Hossain \& Poehling (2006) verified a significant reduction in the emergence of the Opius (Opiothorax) chromatomyiae parasite (Belokobylskij \& Wharton, 2004) (Hymenoptera: Braconidae) after applying $2 \mathrm{~mL} \mathrm{~L}^{-1}$ of spinosad on parasitized hosts.

The low mortality observed with cyromazine on the $O$. scabriventris parasitoid corroborates the results of Araujo et al. (2015). Regarding the insecticide chlorantraniliprole, also with low mortality of $O$. scabriventris, there is no information on its effect on parasitoids from the Opius genus. Chlorantraniliprole is reported to be of low impact for several parasitoids, such as Lysiphlebus testaceipes (Cresson, 1880) (Hymenoptera: Braconidae) (Moscardini et al., 2014; Barros

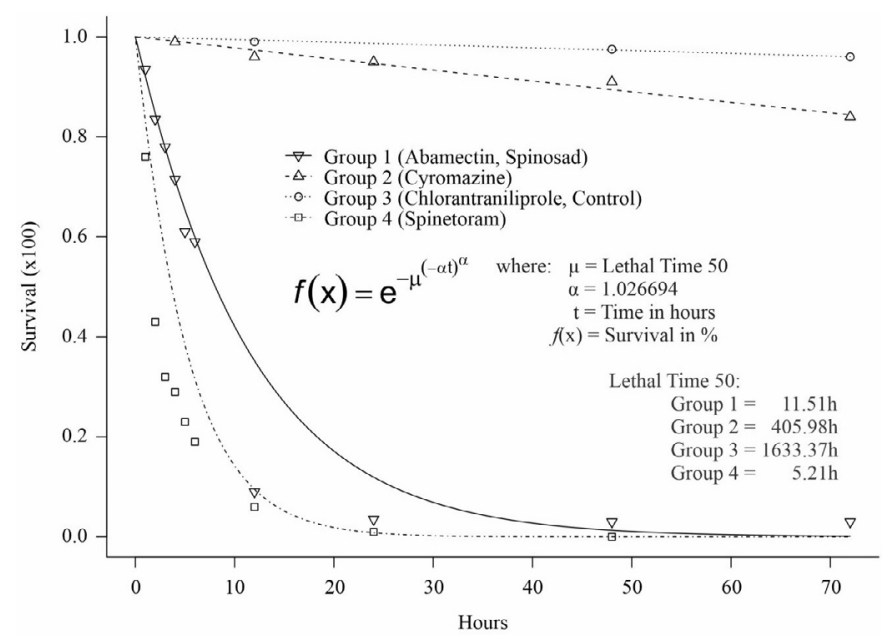

Figure 1. Survival (\%) and lethal times $50\left(\mathrm{LT}_{50}\right)$ in hours of the Opius scabriventris parasitoid, after contact with a freshly sprayed surface with insecticides. et al., 2018), Bracon hebetor (Say, 1857) (Hymenoptera: Braconidae) (Muslim et al., 2018), Aphelinus gossypii Ashmead and Telenomus podisi (Ashmead); slightly to moderately toxic to the adults of Trichogramma pretiosum (Riley, 1879) (Hymenoptera: Trichogrammatidae) (Khan \& Ruberson, 2017; Barros et al., 2018); as low impact for the predators Chrysoperla externa Hagen, Hippodamia convergens GuérinMéneville, Podisus nigrispinus (Dallas), Euborellia annulipes (Lucas) and Solenopsis invicta Buren (Barros et al., 2018); while it was moderately toxic for Eriopis connexa (Germar) and Orius insidiosus (Say). However, Amarasekare \& Shearer (2013) found that chlorantraniliprole was highly toxic for the adults of the predators Chrysoperla carnea (Stephens, 1835) and Chrysoperla johnsoni (Henry, Wells and Pupedis, 1993) (Neuroptera: Chrysopidae), also causing a reduction in their biotic potential. Chlorantraniliprole is from the anthranilamide insecticides class with action on the ryanodine receptors located in the insect muscles, provoking an uncontrolled release of calcium in the sarcoplasmic reticulum (Sial et al., 2012; Jeanguenat, 2013), with its toxic effect on natural enemies depending on the studied species (Gontijo et al., 2014).

As for the sublethal effects, due to the reduced number of surviving insects, only the parasitoids exposed to the insecticides cyromazine and chlorantraniliprole were evaluated, plus the negative control group. The parasitism capacity of the females was significantly affected by these two insecticides. While $100 \%$ of the females from the negative control group were able to successfully parasitize, the ones exposed to chlorantraniliprole and cyromazine demonstrated a significantly lesser parasitism capacity (Figure 2).

The results indicate that the insecticides chlorantraniliprole and cyromazine, despite causing low mortality to adults of the parasitoid, had an effect on their parasitism capacity. This is the first study discussing the sublethal effect of the insecticides chlorantraniliprole and cyromazine on the parasitism capacity of $O$. scabriventris. Reports about the adverse effect of the chlorantriniliprole insecticide on parasitoids are scarce, however, Parsaeyan et al. (2020) observed a negative effect of

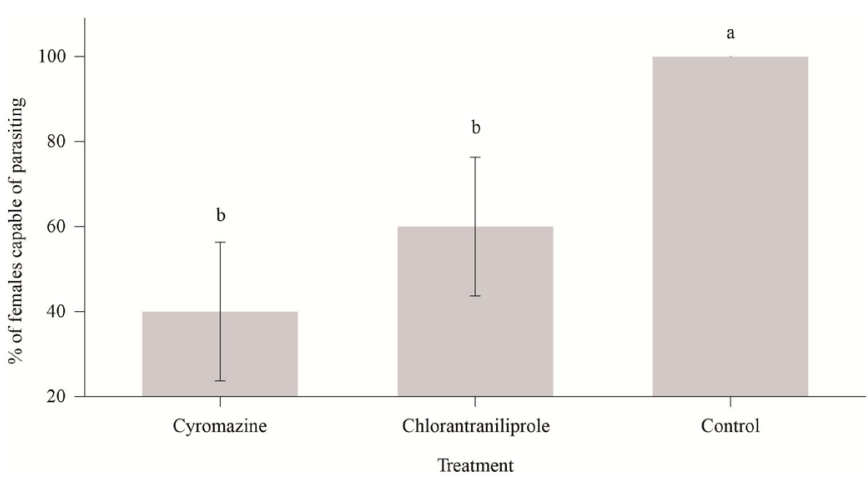

Figure 2 . Percentage of Opius scabriventris females that managed to successfully parasite leafminer larvae after $72 \mathrm{~h}$ of direct exposure to insecticides. Different letters point the significant difference among treatments by the test of KruskalWallis at the $5 \%$ significance level. 
this insecticide on the fertility of the parasitoid Trichogramma brassicae (Bezdenko, 1968) (Hymenoptera: Trichogrammatidae). On the other hand, there are already several reports of the negative effect of chlorantraniliprole on the fertility and longevity of predatory insects, such as, for example, C. carnea (Gontijo et al., 2014), also for the predatory ladybugs Coleomegilla maculata (DeGeer) and $H$. convergens (Coleoptera: Coccinellidae) (Moscardini et al., 2015) and Harmonia axyridis (Pallas) (Coleoptera: Coccinellidae) (Nawaz et al., 2017).

Using products with low toxicity to parasitoids is essential in an IPM program, as it allows integrating biological and chemical controlling methods. The results in this present study suggest that both chlorantraniliprole and cyromazine have negative effects on $O$. scabriventris parasitism, with potential impacts on its reproduction. However, compared to the other studied insecticides and those recommended for the melon crop IPM, chlorantraniliprole and cyromazine demonstrated potential in being used for preserving $O$. scabriventris. Future studies aiming to define the residual time, as well as behavior changes in the parasitoid, among others, will surely help the thoughtful recommendation of these insecticides and preservation of the said parasitoid. Therefore, the results attained may assist in developing new research on the subject, especially under field conditions, also contributing in conserving the $O$. scabriventris parasitoid in the melon production areas.

\section{Conclusions}

The insecticides abamectin, spinetoram and spinosad are harmful to the adults of $O$. scabriventris.

Chlorantraniliprole and cyromazin demonstrate low toxicity (harmless) to the $O$. scabriventris adults. However, they reduce the parasitism capacity of the parasitoid.

\section{Acknowledgements}

The author would like to thank the Coordination for the Improvement of Higher Education Personnel (CAPES), Financing Code 001, and the National Council for Scientific and Technological Development (CNPq) for the master's degree and research productivity scholarships granted to the authors.

\section{Literature Cited}

Abbes, K.; Biondi, A.; Kurtulus, A.; Ricupero, M.; Russo, A.; Siscaro, G.; Zappalà, L. Combined non-target effects of insecticide and high temperature on the parasitoid Bracon nigricans. PloS One, v. 10, n. 9, p. 1-14, 2015. https://doi.org/10.1371/journal.pone.0138411.

Abbott, W.S.A. Method of computing the effectiveness of an insecticide. Journal of Economic Entomology, v. 18, n.2, p. 265267, 1925. https://doi.org/10.1093/jee/18.2.265a.

Agrofit. Sistema de agrotóxicos fitossanitários. http://extranet. agricultura.gov.br/agrofit_cons/principal_agrofit_cons. 4 Jun. 2020.
Amarasekare, K.G.; Shearer, P.W. Comparing effects of insecticides on two green lacewings species, Chrysoperla johnsoni and Chrysoperla carnea (Neuroptera: Chrysopidae). Journal of Economic Entomology, v. 106, n. 3, p. 1126-1133, 2013. https:// doi.org/10.1603/EC12483.

Araujo, E.L.; Nogueira, C.H.F.; Menezes Netto, A.C.; Bezerra, C.E.S. Biological aspects of the leafminer Liriomyza sativae (Diptera: Agromyzidae) on melon (Cucumis melo L.). Ciência Rural, v. 43, n. 4, p. 579-582, 2013. https://doi.org/10.1590/S010384782013000400003.

Araujo, E.L.; Nogueira, C.H.F; Bezerra, C.E.S.; Costa, E.M. Toxicity of insecticides used in melon crops to Opius scabriventris (Hymenoptera: Braconidae). Bioscience Journal, v. 31, n. 5, 2015. https://doi.org/10.14393/BJ-v31n5a2015-26408.

Araujo, E.L.; Pinheiro, S.A.M.; Geremias, L.D.; Menezes Netto, A.C.; Macedo, L.P. M. Técnica de criação da mosca-minadora Liriomyza trifolii (BURGESS) (Diptera: Agromyzidae). Campo Digital, v. 2, n. 1, p. 22-26, 2007. http://revista2.grupointegrado.br/revista/ index.php/campodigital/article/view/317. 13 Mar. 2020.

Barros, E.M.; da Silva-Torres, C.S.A.; Torres, J.B.; Rolim, G.G. Short-term toxicity of insecticides residues to key predators and parasitoids for pest management in cotton. Phytoparasitica, v. 46, n. 3, p. 391404, 2018. https://doi.org/10.1007/s12600-018-0672-8.

Biondi, A.; Mommaerts, V.; Smagghe, G.; Viñuela, E.; Zappalà, L.; Desneux, N. The non-target impact of spinosyns on beneficial arthropods. Pest Management Science, v. 68, n. 12, p. 15231536, 2012. https://doi.org/10.1002/ps.3396.

Biondi, A.; Zappalà, L.; Stark, J.D.; Desneux, N. Do biopesticides affect the demographic traits of a parasitoid wasp and its biocontrol services through sublethal effects? PLoS One, v. 8, n. 9, e76548, 2013. https://doi.org/10.1371/journal.pone.0076548.

Cabral, S.; Soares, A.O.; Garcia, P. Voracity of Coccinella undecimpunctata: effects of insecticides when foraging in a prey/ plant system. Journal of pest science, v. 84, n. 3, p. 373, 2011. https://doi.org/10.1007/s10340-011-0373-2.

Carvalho, G.A.; Carvalho, C.F.; Souza, B.; Ulhôa, J.L.R. Seletividade de inseticidas a Chrysoperla externa (Hagen) (Neuroptera: Chrysopidae). Neotropical Entomology, v. 31, n. 4, p. 615-621, 2002. https://doi.org/10.1590/S1519-566X2002000400015.

Costa, E.M.; Freitas, R.M.O.; Silva, P.A.F.; Araujo, E.L. Determination of damaged leaf area and physiological responses of melon plants submitted to different infestation levels of Liriomyza sativae. Horticultura Brasileira, v. 35, n.4, p. 571-575, 2017. https://doi. org/10.1590/s0102-053620170415.

Costa-Lima, T.C.; Chagas, M.C.M.; Parra, J.R.P. Comparing potential as biocontrol agents of two neotropical parasitoids of Liriomyza sativae. Neotropical Entomology, v. 48, n. 4, p. 660-667, 2019. https://doi.org/10.1007/s13744-018-00667-0.

Costa-Lima, T.C.; Chagas, M.C.M.; Parra, J.R.P. Temperature-dependent development of two neotropical parasitoids of Liriomyza sativae (Diptera: Agromyzidae). Journal of Insect Science, v. 14, n. 1, p. 245, 2014. https://doi.org/10.1093/jisesa/ieu107.

Ferreira, E.C.B.; Freitas, M.T.S.; Sombra, K.D.S.; Siqueira, H.Á.A.; Araujo, E.L.; Balbino, V.Q. Molecular identification of Liriomyza sp. in the Northeast and Southeast regions of Brazil. Revista Caatinga, v. 30, n. 4 , p. 892-900, 2017. https://doi.org/10.1590/198321252017v30n409rc. 
Foba, C.N.; Lagat, Z.O.; Gitonga, L.M.; Akutse, K.S.; Fiaboe, K.K.M. Interaction between Phaedrotoma scabriventris Nixon and Opius dissitus Muesebeck (Hymenoptera: Braconidae): Endoparasitoids of Liriomyza Leafminer. African Entomology, v. 23, n. 1, p. 120131, 2015. https://doi.org/10.4001/003.023.0110.

Gontijo, P.C.; Moscardini, V.F.; Michaud, J.P.; Carvalho, G.A. Non-target effects of chlorantraniliprole and thiamethoxam on Chrysoperla carnea when employed as sunflower seed treatments. Journal of Pest Science, v. 87, n. 4, p. 711-719, 2014. https://doi. org/10.1007/s10340-014-0611-5.

Hossain, M.B.; Poehling, H.M. Non-target effects of three biorationale insecticides on two endolarval parasitoids of Liriomyza sativae (Dip., Agromyzidae). Journal of Applied Entomology, v. 130, n. 6-7, p. 360-367, 2006. https://doi.org/10.1111/j.14390418.2006.01072.x.

Jeanguenat, $A$. The story of a new insecticidal chemistry class: the diamides. Pest Management Science, v. 69, n. 1, p. 7-14, 2013. https://doi.org/10.1002/ps.3406.

Khan, M.A.; Ruberson, J.R. Lethal effects of selected novel pesticides on immature stages of Trichogramma pretiosum (Hymenoptera: Trichogrammatidae). Pest management science, v. 73, n. 12, p. 2465-2472, 2017. https://doi.org/10.1002/ps.4639.

Liu, T.X.; Kang, L.; Lei, Z.; Hernandez, R. Hymenopteran parasitoids and their role in biological control of vegetable Liriomyza leafminers. In: Liu, T.; Kang, L. (Eds.). Recent Advances in Entomological Research. Berlin: Springer, 2011. p.376-403. https://doi.org/10.1007/978-3-642-17815-3_22.

Loetti, V.; Bellocq, I. Effects of the insecticides methoxyfenozide and cypermethrin on non-target arthropods: a field experiment. Austral Entomology, v. 56, n. 3, p. 255-260, 2017. https://doi.org/10.1111/aen.12230.

Moscardini, V.F.; Gontijo, P.C.; Michaud, J.P.; Carvalho, G.A. Sublethal effects of chlorantraniliprole and thiamethoxam seed treatments when Lysiphlebus testaceipes feed on sunflower extrafloral nectar. BioControl, v. 59, n. 5, p. 503-511, 2014. https://doi. org/10.1007/s10526-014-9588-5.

Moscardini, V.F.; Gontijo, P.C.; Michaud, J.P.; Carvalho, G.A. Sublethal effects of insecticide seed treatments on two nearctic lady beetles (Coleoptera: Coccinellidae). Ecotoxicology, v. 24, n. 5, p. 1152-1161, 2015. https://doi.org/10.1007/s10646-0151462-4.

Muslim, M.; Ansari, M. S.; Hasan, F. Non-target toxicity of synthetic insecticides on the biological performance and population growth of Bracon hebetor Say. Ecotoxicology, v. 27, n. 7, p. 10191031, 2018. https://doi.org/10.1007/s10646-018-1947-z.
Nawaz, M.; Cai, W.; Jing, Z.; Zhou, X.; Mabubu, J.I.; Hua, H. Toxicity and sublethal effects of chlorantraniliprole on the development and fecundity of a non-specific predator, the multicolored Asian lady beetle, Harmonia axyridis (Pallas). Chemosphere, v. 178, n. 1, p. 496503, 2017. https://doi.org/10.1016/j.chemosphere.2017.03.082.

Parsaeyan, E.; Saber, M.; Safavi, S.A.; Poorjavad, N.; Biondi, A. Side effects of chlorantraniliprole, phosalone and spinosad on the egg parasitoid, Trichogramma brassicae. Ecotoxicology, v. 1, n. 1, p. 1-10, 2020. https://doi.org/10.1007/s10646-020-02235-y.

R Development Core Team. R: A language and environment for statistical computing. R foundation for statistical computing. Vienna: R Development Core Team, 2019. http://www.r-project. org. 10 Jun. 2020.

Salgado, V.L.; Sheets, J.J.; Watson, G.B.; Schmidt, A.L. Studies on the mode of action of spinosad: the internal effective concentration and the concentration dependence of neural excitation. Pesticide Biochemistry and Physiology, v. 60, n. 2, p. 103-110, 1998. https:// doi.org/10.1006/pest.1998.2333.

Salvo, A.; Valladares, G. Complejo parasítico (Hymenoptera: Parasitica) de Liriomyza huidobrensis (Diptera: Agromyzidae) en haba. Agriscientia, v. 12, n. 1, p. 39-47, 1995. https://doi. org/10.31047/1668.298x.v12.n0.2451.

Sial, A.A.; Brunner, J.F. Baseline toxicity and stage specificity of recently developed reduced-risk insecticides chlorantraniliprole and spinetoram to obliquebanded leafroller, Choristoneura rosaceana (Harris) (Lepidoptera: Tortricidae). Pest Management Science, v. 68, n. 3, p. 469-475, 2012. https://doi.org/10.1002/ps.2296.

Silva, R.K.B. Técnica de criação e aspectos do parasitismo de Opius sp. (Hymenoptera: Braconidae) sobre a mosca-minadora, Liriomyza trifolii (Diptera: Agromyzidae), em meloeiro. Mossoró: Universidade Federal Rural do Semiárido, 2008. 51p. Dissertação Mestrado. http://www2.ufersa.edu.br/portal/view/uploads/ setores/82/Dissertacoes\%202008/DissertacaoRobertaKelia.pdf. 13 Mar. 2019.

Sterk, G., et al. Results of the seventh joint pesticide testing programme carried out by the IOBC/WPRS - Working Group 'Pesticides and Benefical Organisms'. BioControl, v. 44, n. 1, p. 99-177, 1999. https://doi.org/10.1023/A:1009959009802.

Therneau, T. A Package for survival analysis in R. R package version 3.1-8, 2019. https://CRAN.R-project.org/package=survival. 09 Apr. 2019.

Tirello, P.; Pozzebon, A.; Duso, C. The effect of insecticides on the non-target predatory mite Kampimodromus aberrans: laboratory studies. Chemosphere, v. 93, n. 6, p. 1139-1144, 2013. https:// doi.org/10.1016/j.chemosphere.2013.06.046. 